\title{
The vitamin $D$ grey areas in pediatric primary care. Very low serum 25-hydroxyvitamin D levels in asymptomatic children living in northeastern Italy
}

\author{
Stefano Mazzoleni ${ }^{1,4^{*}}$, Daniela Toderini ${ }^{2}$ and Chiara Boscardin ${ }^{3}$
}

\begin{abstract}
The principal questions about the vitamin D topic are far to be resolved: in which children 25-hydroxyvitamin D blood testing is appropriate and how much cholecalciferol should be given in the absence of the test? Analyzing vitamin D status in a group of children cared by a "family pediatrician" in northeastern Italy we noted a high incidence of deficiency in asymptomatic preschool children without risk factors. As routine vitamin $D$ testing is not recommended in the average risk population the supplementation with cholecalciferol represents a "grey area" mostly in pediatric primary care.
\end{abstract}

Keywords: 25-Hydroxyvitamin D, vitamin D, cholecalciferol, deficiency, insufficiency, supplementation

\section{Dear Editor,}

we read with interest the article by Bener and Hoffmann on the incidence of nutritional rickets in a sun rich country like Qatar [1], where decreased vitamin D was a major risk factor. Hypovitaminosis D is highly prevalent in children throughout the world $[2,3]$ but it is still not clear what is the best practice in pediatric primary care settings. Michael Holick, a recognized expert on the topic, has stated that "there is no need to measure everybody's blood 25-hydroxyvitamin D" [25 $(\mathrm{OH}) \mathrm{D}]$ and that only patients with particular diseases should be screened for vitamin D insufficiency/deficiency [4]. Although the literature has shown that patients with deficiency are much less frequent than those with insufficiency, it is also remarkable that vitamin D deficiency is often subclinical and depending on local situations; for example it may be associated with overweight [5] or underweight [1]. To our knowledge there are only a few studies on children living in northeastern Italy [6-8]: they have been conducted retrospectively [6] or examining patients afferent to a Pediatric Department [7] or asthmatic [8]. On this basis an analysis of vitamin D status was prospectively conducted in children cared by a "family pediatrician" in a rural area

\footnotetext{
* Correspondence: stefano.mazzoleni@sanita.padova.it

${ }^{1} \mathrm{MD}$, Pediatra di Libera Scelta, ULSS 16 Regione Veneto, Padova, Italy Full list of author information is available at the end of the article
}

near Padua $\left(45^{\circ} \mathrm{N}\right.$ latitude). In 65 patients the vitamin $\mathrm{D}$ test was included in exams ordered for different reasons (suspected anemia, fatigue, poor growth, etc.) between November 2010 and June 2011. Results were retrieved from 58 children (age range 1.1-15.3 years, median age 6.75 years). Serum 25(OH)D was dosed by chemiluminescence; the laboratory normal range was $75-250 \mathrm{nmol} / \mathrm{l}(30-99 \mathrm{ng} / \mathrm{ml})$; insufficiency was defined as $25-74 \mathrm{nmol} / \mathrm{l}(10-29 \mathrm{ng} / \mathrm{ml})$, deficiency as $<25 \mathrm{nmol} /$ $1(<10 \mathrm{ng} / \mathrm{ml})$.

Most of the children (77\%) had low serum 25(OH)D levels: 38 of them (66\% of all patients) had an insufficiency and 7 (12\%) had a deficiency. Moreover, 29 children $(50 \%)$ had $25(\mathrm{OH}) \mathrm{D}<50 \mathrm{nmol} / \mathrm{l}(<20 \mathrm{ng} / \mathrm{ml})$ that is the cut-off recently suggested to diagnose vitamin $\mathrm{D}$ deficiency $[5,9]$.

None among the 9 young teens (11-15 years) had a normal value of $25(\mathrm{OH}) \mathrm{D}$ and 6 of the 7 children with $25(\mathrm{OH}) \mathrm{D}<25 \mathrm{nmol} / \mathrm{l}(<10 \mathrm{ng} / \mathrm{ml})$ were between ages 2 and 5 years; this deficiency was asymptomatic in $5 / 6$ cases. Moreover, our children with $25(\mathrm{OH}) \mathrm{D} \geq 75$ $\mathrm{nmol} / \mathrm{l}(\geq 30 \mathrm{ng} / \mathrm{ml})$ and those with deficiency didn't differ for exposure to sunlight, food consumption, gender, ethnicity or BMI. Vitamin D status was also irrespective of other blood test results (see Table 1).

Holick has suggested that "it would be much more cost-effective to implement a vitamin D supplementation 
Table 1 Vitamin D status of cases based on laboratory reference ranges (plain text columns) and on recent literature [5,9] (bold columns)

\begin{tabular}{|c|c|c|c|c|c|c|}
\hline & $n$ & Sufficiency & Insufficiency & Deficiency & Insufficiency & Deficiency \\
\hline & & $75-250 \mathrm{nmol} / \mathrm{l}$ & $25-74 \mathrm{nmol} / \mathrm{l}$ & $<25 \mathrm{nmol} / \mathrm{l}$ & $50-74 \mathrm{nmol} / \mathrm{l}$ & $<50 \mathrm{nmol} / \mathrm{l}$ \\
\hline & & $30-99 \mathrm{ng} / \mathrm{ml}$ & $10-29 \mathrm{ng} / \mathrm{ml}$ & $<10 \mathrm{ng} / \mathrm{ml}$ & $20-29 \mathrm{ng} / \mathrm{ml}$ & $<20 \mathrm{ng} / \mathrm{ml}$ \\
\hline $1-5$ years & 27 & $8(30 \%)$ & 13 & $\underline{6}$ & 7 & 12 \\
\hline 6-10 years & 22 & $5(23 \%)$ & 17 & 0 & 5 & 12 \\
\hline $11-15$ years & 9 & 0 & 8 & 1 & 4 & 5 \\
\hline Total & 58 & $13(23 \%)$ & 38 & 7 & 16 & 29 \\
\hline Gender (M/F) & $40 / 18$ & $9 / 4$ & \multicolumn{2}{|c|}{$31 / 14$} & & \\
\hline Overweight & 9 & 3 & \multicolumn{2}{|c|}{6} & & \\
\hline Underweight & 7 & 0 & \multicolumn{2}{|c|}{7} & & \\
\hline Immigrant & 11 & 3 & \multicolumn{2}{|c|}{8} & & \\
\hline Normal exams & 23 & 2 & \multicolumn{2}{|c|}{21} & & \\
\hline
\end{tabular}

program for all children and adults" [4] but the question now is how much vitamin $\mathrm{D}$ should be given. If $400 \mathrm{IU}$ cholecalciferol per day may be sufficient in the first year of life [10], much more is needed in older children, assuming that most of them have less or much less than the minimum desirable [11]. Moreover, recommended doses of 600 IU per day [12] probably offer no advantage to children with $25(\mathrm{OH}) \mathrm{D}<25 \mathrm{nmol} / \mathrm{l}(<10 \mathrm{ng} / \mathrm{ml})$ [13]. Although authoritative guidelines state that routine vitamin $\mathrm{D}$ testing is not warranted in the average risk population, the Holick's D-lemma [4] is far from being resolved.

\section{Abbreviations}

25(OH)D: 25-hydroxyvitamin D.

\section{Author details}

${ }^{1} \mathrm{MD}$, Pediatra di Libera Scelta, ULSS 16 Regione Veneto, Padova, Italy. ${ }^{2} \mathrm{MD}$, Endocrinologa, Medico di Medicina Generale, ULSS 16 Regione Veneto, Padova, Italy. ${ }^{3} \mathrm{MD}$, Borsista Clinica Pediatrica, Università di Padova, Padova, Italy. ${ }^{4}$ Correspondence address: Polistudio Pediatrico, via G. D'Annunzio 3/A, I-35028 Piove di Sacco (Padova), Italy.

\section{Authors' contributions}

MS performed the statistical analysis and interpretation of data and drafted the manuscript. TD participated in the design of the study, in interpretation of data and final approval of the manuscript. BC participated in the collection of data, in the statistical analysis and in the drafting of manuscript. All authors read and approved the final manuscript.

\section{Competing interests}

The authors declare that they have no competing interests.

Received: 24 March 2012 Accepted: 18 April 2012

Published: 18 April 2012

\section{References}

1. Bener A, Hoffmann GF: Nutritional Rickets among Children in a Sun Rich Country. Int J Pediatr Endocrinol 2010, 2010:410502, Epub 2010 Oct 27.

2. Mansbach M, Ginde AA, Camargo CA: Serum 25-Hydroxyvitamin D levels among US children aged 1 to 11 years: do children need more vitamin D? Pediatrics 2009, 124:1404-1410

3. Rathi N, Rathi A: Vitamin D and child health in the 21st century. Indian Pediatr 2011, 48:619-625.
4. Holick MF: The D-lemma: To screen or not to screen for 25Hydroxyvitamin D concentrations. Clin Chem 2010, 56:729-731.

5. Saintonge S, Bang H, Gerber LM: Implications of a new definition of vitamin $D$ deficiency in a multiracial US adolescent population: the National Health and Nutrition Survey III. Pediatrics 2009, 123:797-803.

6. Lippi G, Montagnana M, Targher G: Vitamin D deficiency among Italian children [letter]. CMAJ 2007, 177:1529-1530.

7. Marrone G, Rosso I, Moretti R, Valent F, Romanello C: Is vitamin D status known among children living in Northern Italy? Eur J Nutr 2012, 51:143-149, [Epub 2011 May 4]

8. Chinellato I, Piazza M, Sandri M, Peroni D, Piacentini G, Boner AL: Vitamin D serum levels and markers of asthma control in Italian children. J Pediatr 2011, 158:437-441, Epub 2010 Sep 26.

9. Holick MF: Vitamin D deficiency. N Engl J Med 2007, 357:266-281

10. Mutlu GY, Kusdal Y, Ozsu E, Cizmecioglu FM, Hatun S: Prevention of Vitamin D deficiency in infancy: daily $400 \mathrm{IU}$ vitamin D is sufficient. Int J Pediatr Endocrinol 2011, 2011:4, Epub 2011 Jun 28.

11. Vieth $R$ : Why the minimum desirable serum 25-hydroxyvitamin $D$ level should be $75 \mathrm{nmol} / \mathrm{L}$ (30 ng/ml). Best Pract Res Clin Endocrinol Metab 2011 25:681-691.

12. Abrams SA: Dietary Guidelines for Calcium and Vitamin D: A New Era. Pediatrics 2011, 127:566-568.

13. Heaney RP, Davies KM, Chen TC, Holick MF, Barger-Lux MJ: Human serum 25-hydroxycholecalciferol response to extended oral dosing with cholecalciferol. Am J Clin Nutr 2003, 77:204-210.

doi:10.1186/1687-9856-2012-7

Cite this article as: Mazzoleni et al:: The vitamin D grey areas in pediatric primary care. Very low serum 25-hydroxyvitamin D levels in asymptomatic children living in northeastern Italy. International Journal of Pediatric Endocrinology 2012 2012:7

\section{Submit your next manuscript to BioMed Central and take full advantage of:}

- Convenient online submission

- Thorough peer review

- No space constraints or color figure charges

- Immediate publication on acceptance

- Inclusion in PubMed, CAS, Scopus and Google Scholar

- Research which is freely available for redistribution 